\title{
THE LIMITATIONS AND CAPABILITIES OF WIPE SAMPLES ANALYSIS IN CONTROL OF CONTAMINATION OF FACILITIES WITH HIGHLY TOXIC ORGANIC COMPOUNDS
}

Shachneva MD凶, Leninskii MA, Savelieva El

Research Institute of Hygiene, Occupational Pathology and Human Ecology Leningrad Region, Russia

\begin{abstract}
Wipe sampling is widely used for microbiological control purposes. Sanitary and chemical studies also include analysis of samples wiped from the work surfaces during routine and periodic working conditions safety inspections at chemical facilities. The analysis also allows assessing the toxicity and hazard of items/structures that could be in contact with highly toxic substances. This study aimed to investigate the capabilities and limitations of the surface wipe sample analysis method in control of residual contamination of equipment and building structures of a former chemical weapons destruction facilities (CWDF) with sulfur mustard and O-isobutyl-S(2-diethylaminoethyl) methylphosphonothioate (VR), as well as their degradation products. Gas chromatography with tandem mass spectrometry (GC-MS/MS) enabled identification of the sulfur mustard markers, high-performance liquid chromatography with tandem mass spectrometry (HPLC-MS/MS) allowed identifying VR markers. An assessment of the matrix influence on the results of GC-MS/MS and HPLC-MS/MS analysis was carried out. The matrix effect was established to affect the results the most in case of HPLC-MS/MS analysis: for GC-MS/MS analysis of target substances, the matrix factor averaged at 60-80\%, for HPLC-MS/MS it was less than $40 \%$. The average percent sulfur mustard recoveries from three types of surfaces (PVC tiles, laminate and metal plates) was $9 \pm 2 \%, 0.13 \pm 0.02 \%$ and $0.10 \pm 0.03 \%$; in case of VR, the recoveries was $2.7 \pm 0.5 \%, 11.8 \pm 0.3 \%$ and $0.8 \pm 0.1 \%$, respectively. The limits of detection for sulfur mustard by GC-MS/MS and VR by HPLC-MS/MS were established at $0.001 \mathrm{MPL}$ and $0.02 \mathrm{MPL}$, respectively. The developed approaches were applied to the analysis of wipe samples from the surfaces of the equipment and engineering structures of the former CWDF.
\end{abstract}

Keywords: bis(2-chloroethyl)sulfide, O-isobutyl-S-(2-diethylaminoethyl) methylphosphonothioate, wipe samples, construction materials, gas chromatography, high-performance liquid chromatography, tandem mass spectrometry

Author contribution: Shachneva MD — carrying out the experiment, summarizing the results, article authoring and editing; Leninskii MA — carrying out the experiment, article authoring; Savelieva El — academic advising, article authoring.

$\square$ Correspondence should be addressed: Mariya D. Shachneva

Kapitolovo, r.p. Kuzmolovsky, Vsevolozhsky r., 188663 Leningradskaya obl.; shachneva_mariya@mail.ru

Received: 28.05.2021 Accepted: 14.06.2021 Published online: 26.06.2021

DOI: $10.47183 /$ mes.2021.018

\section{ВОЗМОЖНОСТИ И ОГРАНИЧЕНИЯ АНАЛИЗА СМЫВОВ С ПОВЕРХНОСТЕЙ ДЛЯ КОНТРОЛЯ КОНТАМИНАЦИИ ОБЪЕКТОВ ВЫСОКОТОКСИЧНЫМИ ОРГАНИЧЕСКИМИ СОЕДИНЕНИЯМИ}

\author{
М. Д. Шачнева $\square$, М. А. Ленинский, Е. И. Савельева
}

Научно-исследовательский институт гигиены, профпатологии и экологии человека Федерального медико-биологического агентства, Ленинградская область, Россия

\begin{abstract}
Отбор проб смывов с поверхностей широко применяют в целях микробиологического контроля. В санитарно-химических исследованиях также предусмотрен анализ смывов с рабочих поверхностей при проведении плановых и периодических проверок безопасности условий труда работников химических предприятий, а также для оценки токсичности и опасности объектов, которые могли находиться в контакте с высокотоксичными веществами. Целью работы было исследовать возможности и ограничения метода анализа смывов с поверхностей для контроля остаточного загрязнения оборудования и строительных конструкций бывшего предприятия по уничтожению химического оружия (УХО) сернистым ипритом и О-изобутил-S(2-диэтиламиноэтил)-метилфоссонотиоатом (VR), а также продуктами их трансформации. Маркеры иприта определяли методом газовой хроматографии с тандемным масс-спектрометрическим детектированием (ГХ-MC/MC), маркеры VR - методом жидкостной хроматограсрии с тандемным массспектрометрическим детектированием (ВЭЖХ-МС/MC). Проведена оценка матричного влияния на результаты ГХ-МС/МС и ВЭЖХ-МС/МС анализа. Показано, что матричное влияние наиболее существенно при анализе методом ВЭЖХ-МС/МС: матричный фактор при определении аналитов методом ГХ-МС/МС составил в среднем 60-80\%, методом ВЭЖХ-МС/МС - менее 40\%. Степень извлечения аналитов с трех типов поверхностей (плитки из

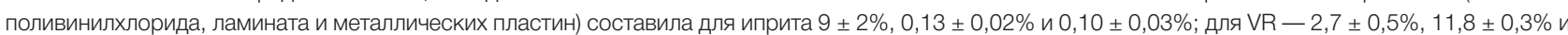

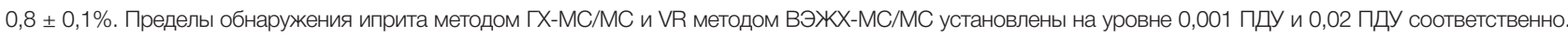
Разработанные подходы применены при анализе смывов с поверхностей оборудования и инженерных конструкций бывшего предприятия УХО.
\end{abstract}

Ключевые слова: бис(2-хлорэтил)сульсид, О-изобутил-S-(2-диэтиламиноэтил)-метилфоссонотиоат, смывы с поверхности, строительные материалы, газовая хроматография, высокоэффективная жидкостная хроматография, тандемное масс-спектрометрическое детектирование

Вклад авторов: М. Д. Шачнева - проведение эксперимента, обобщение результатов, написание и редактирование статьи; М. А. Ленинский проведение эксперимента, написание статьи; Е. И. Савельева - научное руководство, написание статьи.

$\bowtie$ Для корреспонденции: Мария Дмитриевна Шачнева Ст. Капитолово, г. п. Кузьмоловский, Всеволожский район, 188663, Ленинградская область; shachneva_mariya@mail.ru

Статья получена: 28.05.2021 Статья принята к печати: 14.06.2021 Опубликована онлайн: 26.06.2021

DOI: $10.47183 /$ mes.2021.018

The detection of toxic substances and their degradation products on the surfaces and in the deep layers of building materials is relevant for assessment of safety of infrastructure elements of former chemical weapons destruction facilities (CWDF) planned for conversion, as well as for investigations of incidents in the context of terrorist attacks or events of unintentional contact with buried chemical weapons.

There are regulations that govern activities of the federal state sanitary and epidemiological authorities supervising decommissioning and relief of consequences of operation of the chemical weapons storage and destruction facilities. A final conclusion on the safety of infrastructure of the facilities to be converted and used for civilian purposes requires comprehensive studies that include analysis of wipe samples from various surfaces within the facility. In a specific case of one of the CWDFs, sanitary and chemical studies enabling assessment of the process equipment and engineering infrastructure's safety were aimed at identifying the elements, 
units etc that had no traces of contamination with sulfur mustard and organophosphorus toxic substances. Bis (2-chloroethyl) sulfide (sulfur mustard) and O-isobutyl-S-(2-diethylaminoethyl) methylphosphonothioate (VR) were chosen as persistent markers of contamination.

Sulfur mustard is a blistering agent, a persistent organochlorine compound; it is easily sorbed on absorbent porous surfaces and can retain its ecotoxic properties for decades. The action of sulfur mustard is distinctly local: it affects the eyes and the respiratory organs, the gastrointestinal tract and the skin. Absorbed into the blood, it also acts as a systemic poison. 1,4-dithiane, one of the stable products of sulfur mustard degradation under chemical detoxification, was chosen as an analyte for control of contamination of the surfaces with the reaction masses from sulfur mustard destruction [1]. The detection of sulfur mustard in combination with 1,4-dithiane, a stable product of its degradation, increases the reliability of retrospective analysis.

As cholinesterase inhibitors, nerve agents (NA), including VR, act when inhaled, ingested or applied to skin. In the body, NA triggers excessive accumulation of acetylcholine and overexcitation of cholinergic receptors. The typical signs and symptoms of their effect are miosis, nausea, chest tightness, increased salivation and sweating, and lacrimation [2].

Compared to G-agents (sarin, soman) under similar conditions, V-agents, VR in particular, are less volatile and more persistent [3]. Consequently, a retrospective analysis of samples taken from the infrastructure of former CWDFs may reveal both the products of their detoxification and the VR itself. The most toxic product of VR hydrolysis is S-2-(diethylaminoethyl) methylphosphonothioate (DEAEMPT). By analogy with S-2(diisopropylaminoethyl)-methylphosphonothioate, which is the most toxic product of hydrolysis of $\mathrm{VX}$, DEAEMPT is only 3-10 times less toxic than VR [2], yet there were no hygienic standards developed for this extremely dangerous substance.

Wipe sampling is one of the most common sampling patterns in the context of examination of surfaces for contamination with toxic substances (pesticides, toxic metals, toxic substances, etc). However, the toxicants can penetrate deep into porous materials and become hard to extract, which is why wipe sampling is considered a method suitable only for non-porous materials. The gauze swabs used for wipe sampling should also be considered as a matrix capable of absorbing the analyte. Surface wiping brings target substances into the swab, from they are recovered with the help of the extracting solvent. A significant amount of analytes may be lost at both of these stages. The efficiency of extraction of analytes from the swabs can be established in model experiments and factored into the quantitative assessment of surface contamination of the controlled items. The possibility of recovery of analytes from the surfaces of specific materials and the efficiency of such recovery should be established through preliminary experiments with application of the target substances to the materials with the same surface texture as those of the controlled item.

This study aimed to investigate the capabilities and limitations of wipe sampling as applied to process equipment in the context of assessment of safety of infrastructure of the former CWDFs planned for conversion and subsequent use for civilian purposes.

\section{METHODS}

\section{Reagents and materials}

Sulfur mustard (GSO 8248-2003; Russia); O-isobutylS-(2-diethylaminoethyl) methylthiophosphonate, or VR
(GSO 8249-2004; Russia); 1,4-dithiane (Sigma-Aldrich; USA); S-[(2-diethylamino)ethyl] methylphosphonothioate, or DEAEMPT (enterprise standard 4/2019, Russia); methylene chloride (Supelco; USA); acetonitrile (Panreac; Spain); HPLC methanol (J.T. Baker; USA); formic acid (Sigma-Aldrich; USA).

\section{Study items}

Three types of materials were selected to investigate the efficiency of wipe sampling: PVC tiles, laminate and metal plates. The swabs were made of $10 \times 10 \mathrm{~cm}$ sections of medical gauze, treated with acetonitrile in a Soxhlet for 6-8 h, dried and folded in 16 layers.

\section{Model samples}

A solution of sulfur mustard and 1,4-dithiane in methylene chloride was applied to a $1 \mathrm{dm}^{2}$ area of the studied surfaces free from the target compounds, with the target concentration of each substance being $100 \mathrm{ng} / \mathrm{dm}^{2}$. The VR and DEAEMPT application conditions were the same, but their target concentrations were $50 \mathrm{ng} / \mathrm{dm}^{2}$. The samples were kept in a fume hood for 30 minutes.

\section{Wipe sampling}

A part of the controlled surface was sequentially wiped with two swabs moistened with methylene chloride (for sulfur mustard and 1,4-dithiane detection) or acetonitrile (for VR and DEAEMPT detection), and one dry swab. All three swabs were placed in a $7 \mathrm{ml}$ vial, capped and stored at $-20^{\circ} \mathrm{C}$ until analysis.

\section{Sample preparation for sulfur mustard and 1,4-dithiane determination}

Four $\mathrm{ml}$ of methylene chloride were added to the test sample (3 gauze swabs wiped against the surface). Target analytes were ultrasonically extracted for 5 minutes. The extract was transferred to a $7 \mathrm{ml}$ vial and the extraction procedure was repeated. The extracts were then combined and concentrated under a stream of nitrogen to a final volume of $0.2 \mathrm{ml}$ at room temperature. Two $\mu$ of the extract aliquot were analyzed by gas chromatography with tandem mass spectrometry in the electron ionization mode (GC-MS/MS-EI).

\section{Sample preparation for VR and DEAEMPT determination}

Four $\mathrm{ml}$ of methanol were added to a vial with swabs wiped against the surface. Target analytes were ultrasonically extracted for 5 minutes. The extract was transferred to a $7 \mathrm{ml}$ vial and the extraction procedure was repeated. The extracts were combined, concentrated under a stream of nitrogen to a final volume of $0.1 \mathrm{ml}$, then $0.2 \mu \mathrm{l}$ of $0.1 \%$ aqueous formic acid solution were added thereto and the resulting solution analyzed by high performance liquid chromatography with tandem mass spectrometry (HPLC-MS/MS).

\section{Equipment and conditions for instrumental analysis}

For sulfur mustard and 1,4-dithiane detection, we used a $7890 \mathrm{~A}$ gas chromatograph with a 7000 mass-selective detector with triple quadrupole (Agilent Technologies; USA) equipped with an HP-5MS capillary quartz column: $30 \mathrm{~m} \times 0.25 \mathrm{~mm} \times 0.25 \mu \mathrm{m}$ (Agilent Technologies; USA). Analysis conditions: injector temperature $-270{ }^{\circ} \mathrm{C}$; sample injection without flow splitting - 
Table 1. Detection parameters, sulfur mustard and 1,4-dithiane detected by GC-MS/MS-EI, VR and DEAEMPT by HPLC-MS/MS

\begin{tabular}{|c|c|c|}
\hline Compound detected & MRM transition (collision energy) & Retention time, min \\
\hline Sulfur mustard & $\begin{array}{c}109 \rightarrow 63(6 \mathrm{eV}) \\
158 \rightarrow 109(3 \mathrm{eV})\end{array}$ & 9 \\
\hline 1,4 -dithiane & $\begin{array}{c}120 \rightarrow 61(6 \mathrm{eV}) \\
120 \rightarrow 105(3 \mathrm{eV})\end{array}$ & 7.4 \\
\hline VR & $268,00 \rightarrow 100,10(-25 \mathrm{~V})$ \\
$268,00 \rightarrow 72,05(-34 \mathrm{~V})$ & 3.65 \\
\hline DEAEMPT & $212,10 \rightarrow 100,10(-20 \mathrm{~V})$ & 1.22 \\
\hline
\end{tabular}

1.0 minute; temperature program: $40^{\circ} \mathrm{C}(0 \mathrm{~min})-10^{\circ} \mathrm{C} / \mathrm{min}-$ $230^{\circ} \mathrm{C}(5$ minutes $)-15^{\circ} \mathrm{C} / \mathrm{min}-280^{\circ} \mathrm{C}(5$ minutes $)$; carrier gas - helium; carrier gas flow rate $-1 \mathrm{ml} / \mathrm{min}$; ion source temperature $-230^{\circ} \mathrm{C}$; interface temperature $-280^{\circ} \mathrm{C}$; energy of ionizing electrons - $70 \mathrm{eV}$; detection mode - multiple reaction monitoring (MRM) in the electron ionization (El) mode.

For VR and DEAEMPT detection, we used an LC-20AD liquid chromatograph equipped with an autosampler and an LCMS-8050 mass-selective detector with electrospray ionization at atmospheric pressure (Shimadzu; Japan). Gemini-NX 3u C18 110A chromatographic column (Phenomenex; USA): $150 \mathrm{~mm}$ $\times 0.2 \mathrm{~mm} \times 3.0 \mu \mathrm{m}$. Mass spectrometry parameters: drying gas flow rate $-10 \mathrm{ml} / \mathrm{min}$; auxiliary gas flow rate $-10 \mathrm{ml} / \mathrm{min}$; flow rate at the electrospray - $3 \mathrm{ml} / \mathrm{min}$; interface temperature $200{ }^{\circ} \mathrm{C}$; desolvation line temperature $-250{ }^{\circ} \mathrm{C}$; heater temperature $-350^{\circ} \mathrm{C}$; capillary voltage $-3500 \mathrm{~V}$; detection mode - MRM with registration of positively charged ions.

Table 1 shows the parameters for detection of sulfur mustard and 1,4-dithiane by GC-MS/MS-EI, VR and DEAEMPT by HPLC-MS/MS. Microsoft Excel (Microsoft; USA) enabled statistical processing of the data.

\section{RESULTS}

The methods developed to control contamination of work surfaces with sulfur mustard and VR rely on wipe sampling with cotton-gauze swabs. One of the studies [4] explores various swab material options (cotton wool, fabric, filter paper, fiberglass, etc). Fabric swabs delivered the best results. We compared the effectiveness of cotton-gauze and gauze swabs in extraction of a wide range of contaminants experimentally and found that swabs made of folded (several layers) gauze recovered more analytes from any surface, regardless of their nature. Therefore, we used swabs of $10 \times 10 \mathrm{~cm}$ pieces of medical gauze folded in several layers, washed with solvents and dried.

In case of wipe samples taken from the process equipment, the maximum permissible level (MPL) of sulfur mustard is $2 \times 10^{-4} \mathrm{mg} / \mathrm{dm}^{2}$, that of for VR $-2 \times 10^{-6} \mathrm{mg} / \mathrm{dm}^{2}$ [5]. The established hygienic standards set the requirements for sensitivity of analysis methods. For wipe samples from surfaces, the limit of detection (LOD) for sulfur mustard was set at $2 \times 10^{-7} \mathrm{mg} / \mathrm{dm}^{2}$ (0.001 MPL), that for 1,4-dithiane $-5 \times 10^{-8} \mathrm{mg} / \mathrm{dm}^{2}$. The LODs for DEAEMPT and VR were $6.5 \times 10^{-8}$ and $4.1 \times 10^{-8} \mathrm{mg} / \mathrm{dm}^{2}$ (0.02 MPL), respectively [6]. The tandem mass spectrometry detectors used ensured reliable identification of the analytes even at the lower detection limit.

\section{Assessment of the matrix effect}

The matrix factor was calculated with the help of the postextraction addition method: extracts from swabs (single, double, triple extraction) that did not contain analytes were analyzed after sulfur mustard and 1,4-dithiane or VR and DEAEMPT were added to them. The results obtained were compared with the results of analysis of the target compounds in a pure solvent, using formula 1. To assess the matrix factor for two- and three-fold extraction, the analytes were added to the combined extract:

$$
\mathrm{MF}=\frac{s_{p r}}{s_{r}} \times 100 \%,
$$

where MF is the matrix factor; Spr is the peak area of the analyte in the extract from swabs containing no sulfur mustard, 1,4-dithiane, VR, or DEAEMPT, after adding the target compounds to them; $\mathrm{Sr}$ is the peak area of the analyte in a pure solvent.

Table 2 shows the results of matrix factor (MF) calculation.

\section{Extraction efficiency of the analytes from gauze swabs}

In order to determine the extraction efficiency of sulfur mustard, 1,4-dithiane, VR, and DEAEMPT from gauze swabs, we placed three swabs in $7 \mathrm{ml}$ vials and added each analyte in concentration of $50 \mathrm{ng} / \mathrm{ml}$. After that, we carried out single, double, triple extraction of the target compounds with an appropriate solvent: methylene chloride for sulfur mustard and 1,4-dithiane, methanol for VR and DEAEMPT (see Figure).

The extraction efficiency was estimated using formula 2 :

$$
\mathrm{EE}=\frac{s_{p r}}{s_{r}} \times 100 \%,
$$

where EE is the extraction efficiency, \%; $S_{p r}$ is the analyte peak area in the extract from swabs with the target compounds added; $S_{r}$ is the analyte peak area in a pure solvent.

\section{Determination of the percent recovery of sulfur mustard and 1,4-dithiane, VR and DEAEMPT from various surfaces}

Table 3 shows the results of determining the percent recovery of sulfur mustard and 1,4-dithiane, VR and DEAEMPT from three types of surfaces the substances were applied to.

Table 2. Matrix factor (\%) in detection of sulfur mustard and 1,4-dithiane by GC-MS/MS, VR and DEAEMPT by HPLC-MS/MS, after adding the analytes to the extracts from blank swabs

\begin{tabular}{|c|c|c|c|}
\hline Parameter & Sulfur mustard & 1,4-dithiane & DEAEMPT \\
\hline MF, single extraction, $\%( \pm$ SD) & $67 \pm 4$ & $64 \pm 6$ & $21 \pm 6$ \\
\hline MF, double extraction, $\%( \pm$ SD) & $61 \pm 3 \pm 4$ & $71 \pm 5$ & $39 \pm 4$ \\
\hline MF, triple extraction, $\%( \pm$ SD) & $58 \pm 6$ & $76 \pm 8$ & $24 \pm 11$ \\
\hline
\end{tabular}




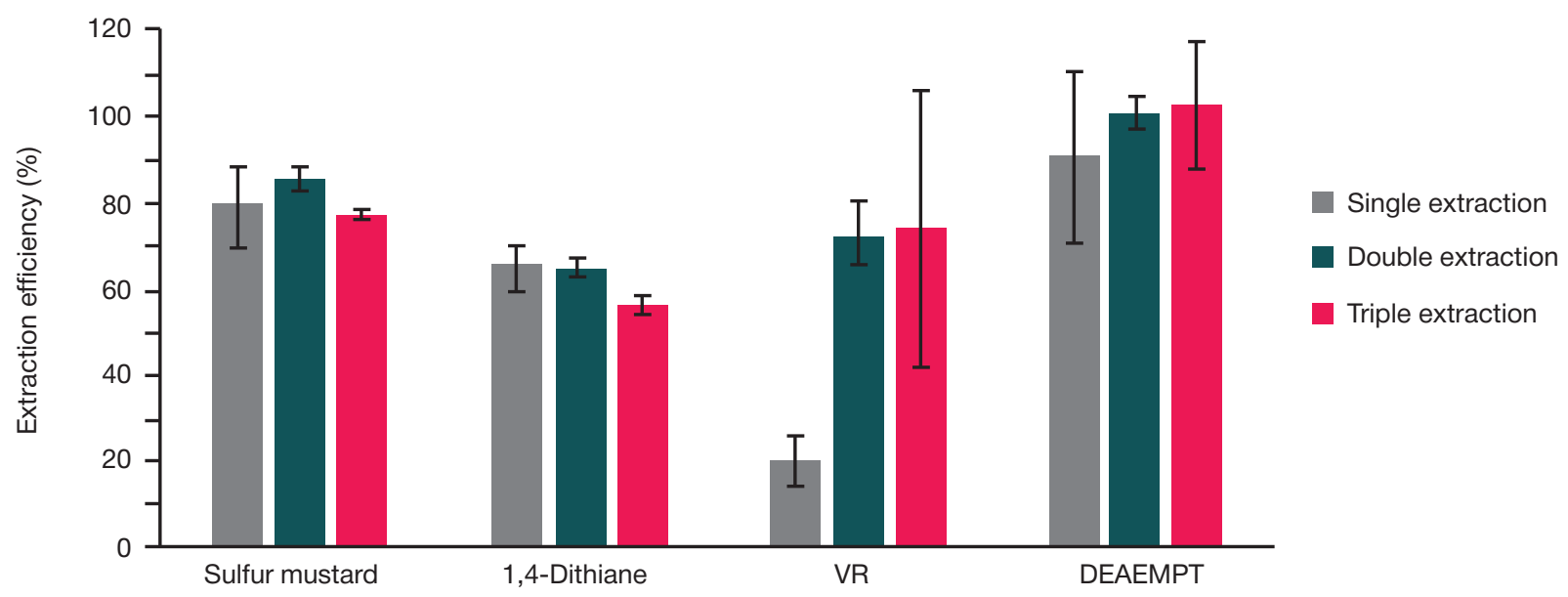

Fig. Extraction efficiency of the target compounds from gauze swabs

\section{Analysis of wipe samples taken from surfaces of equipment and infrastructure of a former CWDF}

The developed procedures for determination of sulfur mustard and 1,4-dithiane (by GC-MS/MS), VR and DEAEMPT (by HPLC-MS/MS) were applied in the context of analysis of the wipe samples taken from the elements of engineering infrastructure and building structures of a former CWDF. To test the developed approach, we analyzed wipe samples taken in the contaminated area, is not included in the conversion program.

Sulfur mustard was detected in 5 samples (out of 15), its level ranging from $2 \times 10^{-7}$ to $2 \times 10^{-6} \mathrm{mg} / \mathrm{dm}^{2} ; 1$, 4 -dithiane was identified in 12 samples (out of 15 ) its level ranging from $3 \times 10^{-6}$ to $1.5 \times 10^{-4} \mathrm{mg} / \mathrm{dm}^{2}$.

Sixty-two samples were taken in the buildings where organophosphorus agents were destroyed. VR and DEAEMPT were identified in 22 and 20 samples, respectively. The concentrations of VR and DEAEMPT on surfaces were estimated to range from $3.3 \times 10^{-6}$ to $5.2 \times 10^{-4} \mathrm{mg} / \mathrm{dm}^{2}$ and from $3.3 \times 10^{-7}$ to $1.0 \times 10^{-5} \mathrm{mg} / \mathrm{dm}^{2}$, respectively.

\section{DISCUSSION}

According to the results of the experiments, in detection of sulfur mustard and 1,4-dithiane by GC-MS/MS the matrix factor averaged at $60-80 \%$, with the number of extractions not affecting the figure significantly.

For VR and DEAEMPT the matrix factor is more pronounced. This is an expected result; it is caused by a well-known effect that hinders quantitative determinations by HPLC-MS/MS with electrospray ionization, the effect of signal suppression by the matrix [7]. The effect is mainly associated with the microdroplets charge [8] weakening during electrospraying or with saturation of the droplet surface with analyte molecules, which hinders ejection of ions from inside the droplet [9]. For ionization methods compatible with gas chromatography, and for electron ionization, in particular, the matrix effect is insignificant. In the detection of sulfur mustard and 1,4-dithiane, the matrix factor is still below $100 \%$, which is due to the increased level of noise recorded in the extract in comparison with the calibration solution. Under the given analyte extraction conditions (extraction from swabs), the matrix factor for all analytes was at least $20 \%$, which allows characterizing the analysis procedures as selective.

The results of the double extraction of sulfur mustard and 1,4-dithiane from gauze swabs are more reproducible due to elimination of such subjective factor as fullness of the solvent removal from the swab during squeezing. Third extraction in the row affected the result negatively. The volume of the extraction solvent was larger, therefore, extract concentration in the nitrogen stream took longer, which resulted in loss of analytes.

Only VR recovery changed significantly with the growing number of extractions. With single extraction, the percent recovery was $20 \%$, with double extraction it increased to $73 \%$. A third extraction did not boost the recovery efficiency of VR and DEAEMPT significantly but increased the measurement error.

The experiments allowed selecting double extraction as the optimal approach, which enables extraction of $86 \%$, $65 \%, 73 \%$, and $100 \%$ of sulfur mustard, 1,4-dithiane, VR, and DEAEMPT respectively.

The values of sulfur mustard recovery from the surfaces learned in this study are low $(0.1-9 \%)$, which is consistent with the literature data. This substance was extracted best from wipe samples taken from the surface of glazed tiles, varnished wooden surfaces and stainless steel (50\%, 30\% and 20\% respectively). In the cases of other types of surfaces (painted plasterboard, ceiling tiles, smooth cement, upholstery fabric, wooden surface untreated with varnish, escalator railings), the recovery of sulfur mustard was in the range of $0.3-7.6 \%[10]$.

Table 3. The percent recovery of sulfur mustard and 1,4-dithiane, VR and DEAEMPT from various surfaces

\begin{tabular}{|l|c|c|c|c|}
\hline \multirow{2}{*}{ Material } & \multicolumn{4}{|c|}{ Recovery, \% ( \pm SD $)$} \\
\cline { 2 - 5 } & Sulfur mustard & 1,4 -dithiane & VR & DEAEMPT \\
\hline PVC tile & $9 \pm 2$ & $5 \pm 1$ & $2.7 \pm 0.5$ & $4.8 \pm 0.1$ \\
\hline Laminate & $0.13 \pm 0.02$ & $-{ }^{*}$ & $11.8 \pm 0.3$ & $5.7 \pm 0.2$ \\
\hline Metal & $0.10 \pm 0.03$ & - & $0.8 \pm 0.1$ & $7.0 \pm 1.1$ \\
\hline
\end{tabular}

Note: * - below LOD of 1,4-dithiane $\left(5 \times 10^{-8} \mathrm{mg} / \mathrm{dm}^{2}\right)$. 
It is expedient to consider the results of VR and DEAEMPT detection in wipe samples taken from three types of surfaces in comparison with work [11], which explored the possibility of extracting degradation products of organophosphorus agents from wipe samples taken from painted plasterboard and laminate surfaces. Immediately after application, it is possible to extract $56-74 \%$ of monoalkyl esters of methylphosphonic acid (MPA) from the surface of painted plasterboard, and even after 42 days, $14-26 \%$ of the initially introduced amount can be detected. For MPA, the extraction percentage does not change from day 0 to day 42 ; within this period, it can be $7-16 \%$. All of the listed compounds are stable, polar, non-volatile. The only non-polar volatile substance in the group of analytes studied was diisopropyl ester of MPA. It could not be detected even directly after application to a painted plasterboard. A similar picture was registered in the experiment with laminate. The author of the study cited above believes it is volatility that prevents detection of the diisopropyl ester of MPA on the surface even immediately after its application.

It may take minutes or years for a toxicant to disappear from the surface by evaporation, degradation or penetration deep into the matrix with irreversible retention therein. The factors determining this duration are the chemical nature of the toxicant, which determines its stability, volatility, sorption activity, viscosity, ability to self-encapsulate, and the type of material: porosity of the structure, hydrophilic-hydrophobic properties, sorption capacity, presence of catalytically active centers, etc. The variety of the above factors and the complex nature of their interplay disallow accurate prediction of the usefulness of wipe samples in establishing the fact of contamination of an item/element etc with target compounds. Moreover, it is not possible to predict if wipe sampling, in any given case, will be possible, feasible and deliver the information expected.

The search for residual toxic substances at the former CWDF returned positive results in wipe samples taken from the surfaces of cable conduits (polymer with a dense nonabsorbent texture), lighting shades (plexiglass), painted coatings of fire points and containers made of polycarbonate. At first glance, it is incredible that toxic substances and their degradation products were detected on the surfaces long after all work related to the destruction of chemical weapons was over. We attribute this result to repeated cleaning of surfaces, first with degassing solutions, and then with large amounts of water. Apparently, degassing affected only the surface layers of materials, and water penetrated deep into the materials with a porous structure. Subsequently, pushed by leaching and capillary forces, the toxic substances and their degradation products could have migrated into the surface layers of the materials. In the process, they were partially hydrolyzed. This assumption is confirmed by the fact that surface contamination was established mainly for those materials that also proved to have their deep layers contaminated, although there was no unconditional correlation between deep and surface contamination established. Researching the literature available, we failed to find studies investigating migration of the target toxic substances from deep layers of the materials to their surface layers. Taking into account the ecological significance of this process, it is advisable to study it comprehensively.

All elements of the CWDF infrastructure that had signs of residual contamination with toxic substances were sent for destruction.

\section{CONCLUSIONS}

Wipe sampling from equipment or building structures in the context of assessment of their contamination with chemical agents allows keeping the said equipment and structures intact, while the levels of contamination thus established reflect the danger of contact with them and the related possibility of emission of volatile compounds into the air. Despite the established effect of matrix suppression, which is significant, HPLC-MS/MS is capable of detecting VR and toxic products of its hydrolysis in wipe samples, the detection being highly sensitive and direct. In case of sulfur mustard and 1,4-dithiane, GC-MS/MS proves to be highly sensitive and selective while being much less influenced by the matrix factor. After wiping, wet swabs can be sealed in an inert container, frozen and stored for a short time or transported. There is no unconditional correlation between toxicant content on the surface and in the deep layers of the materials, therefore, along with the analysis of wipe samples, it is necessary to analyze the samples of deep layers of building and other materials if there is a suspicion they may have been contaminated with toxic substances.

\section{References}

1. Saveleva El, Radilov AS, Kuznecova TA, Apraksin VF. Issledovanie sostava gazovydelenij bitumno-solevyh mass, vkljuchajushhih produkty unichtozhenija iprita. Zhurnal prikladnoj himii. 1999; 72 (9): 1501-5. Russian.

2. Munro NB, Talmage SS, Griffin GD, Waters LC, Watson AP, King JF, et al. The sources, fate, and toxicity of chemical warfare agent degradation products. Environmental Health Perspectives. 1999 107 (12): 933-74.

3. Crenshaw MD, Hayes TL, Miller TL, Shahnuon CM. Comparison of the hydrolytic stability of S-(N,N-diethylaminoethyl) isobuty methylphosphonothiolate with VX in dilute solution. J Appl Toxicol. 2001; 21 (S3-S6): 53-56.

4. Willison S. Wipe selection for the analysis of surface materials containing chemical warfare agent nitrogen mustard degradation products by ultra-high pressure liquid chromatography-tandem mass spectrometry. Journal of Chromatography A. 2012; 1270: 72-79.

5. Postanovlenie Glavnogo gosudarstvennogo sanitarnogo vracha Rossijskoj Federacii ot 28.01.2021 \# 2 «Ob utverzhdenii sanitarnyh pravil i norm SanPiN 1.2.3685-21 «Gigienicheskie normativy i

trebovanija k obespecheniju bezopasnosti i (ili) bezvrednosti dlja cheloveka faktorov sredy obitanija" (Zaregistrirovano 29.01.2021 \# 62296). Available from: https://docs.cntd.ru/ document/573500115 (data obrashhenija: 25.05.2021). Russian.

6. Saveleva EI, Leninskii MA, Vasileva IA, Karakashev GV, Samchenko NA. Opredelenie sledovyh kolichestv O-izobutil-S[(2-dijetilamino)jetil] metilfosfonotioata i toksichnogo produkta ego gidroliza metodom vysokojeffektivnoj zhidkostnoj hromatografii $\mathrm{s}$ tandemnym mass-spektrometricheskim detektirovaniem. Analitika i kontrol'. 2021; 25 (3): 43. Russian.

7. Annesley TM. Ion Suppression in Mass Spectrometry. Clin. Chem. 2003; 49: 1041-4

8. Jessome LL, Volmer DA. Ion Suppression: A Major Concern in Mass Spectrometry. LCGC North America. 2006; 24: 498-511.

9. Antignac J, Wasch K, Monteau F, Brabander H, Andre F, Le Bizec B. The ion suppression phenomenon in liquid chromatographymass spectrometry and its consequences in the field of residue analysis. Anal Chim Acta. 2005; 529: 129.

10. Hernon-Kenny LA, Behringer DL, Crenshaw MD. Comparison of latex body paint with wetted gauze wipes for sampling the 
chemical warfare agents $\mathrm{VX}$ and sulfur mustard from common indoor surfaces. Forensic Science International. 2016; 262: 143-9.

11. Wilson SA. Investigation of the Persistence of Nerve Agent

\section{Литература}

1. Савельева Е. И., Радилов А. С., Кузнецова Т. А., Апраксин В. Ф. Исследование состава газовыделений битумно-солевых масс, включающих продукты уничтожения иприта. Журнал прикладной химии. 1999; 72 (9): 1501-5.

2. Munro NB, Talmage SS, Griffin GD, Waters LC, Watson AP, King JF, et al. The sources, fate, and toxicity of chemical warfare agent degradation products. Environmental Health Perspectives. 1999. 107 (12): 933-74.

3. Crenshaw MD, Hayes TL, Miller TL, Shahnuon CM. Comparison of the hydrolytic stability of S-(N,N-diethylaminoethyl) isobutyl methylphosphonothiolate with VX in dilute solution. J Appl Toxicol. 2001; 21 (S3-S6): 53-56.

4. Willison S. Wipe selection for the analysis of surface materials containing chemical warfare agent nitrogen mustard degradation products by ultra-high pressure liquid chromatography-tandem mass spectrometry. Journal of Chromatography A. 2012; 1270: 72-79.

5. Постановление Главного государственного санитарного врача Российской Федерации от 28.01.2021 № 2 "Об утверждении санитарных правил и норм СанПиН 1.2.368521 «Гигиенические нормативы и требования к обеспечению безопасности и (или) безвредности для человека факторов среды обитания" (Зарегистрировано 29.01.2021 № 62296). Available from: https://docs.cntd.ru/document/573500115 (дата
Degradation Analytes on Surfaces through Wipe Sampling and Detection with Ultrahigh Performance Liquid ChromatographyTandem Mass Spectrometry. Anal Chem. 2015; 87: 1034-41.

обращения: 25.05.2021).

6. Савельева Е. И., Ленинский М. А., Васильева И. А., Каракашев Г. В., Самченко Н. А. Определение следовых количеств О-изобутил-S-[(2-диэтиламино)этил] метилфосфонотиоата и токсичного продукта его гидролиза методом высокоэффективной жидкостной хроматографии с тандемным масс-спектрометрическим детектированием. Аналитика и контроль. 2021; 25 (3): 43.

7. Annesley TM. Ion Suppression in Mass Spectrometry. Clin. Chem. 2003; 49: 1041-4.

8. Jessome LL, Volmer DA. Ion Suppression: A Major Concern in Mass Spectrometry. LCGC North America. 2006; 24: 498-511.

9. Antignac J, Wasch K, Monteau F, Brabander H, Andre F, Le Bizec B. The ion suppression phenomenon in liquid chromatographymass spectrometry and its consequences in the field of residue analysis. Anal Chim Acta. 2005; 529: 129.

10. Hernon-Kenny LA, Behringer DL, Crenshaw MD. Comparison of latex body paint with wetted gauze wipes for sampling the chemical warfare agents $\mathrm{VX}$ and sulfur mustard from common indoor surfaces. Forensic Science International. 2016; 262: 143-9.

11. Wilson SA. Investigation of the Persistence of Nerve Agent Degradation Analytes on Surfaces through Wipe Sampling and Detection with Ultrahigh Performance Liquid ChromatographyTandem Mass Spectrometry. Anal Chem. 2015; 87: 1034-41. 